\title{
Risk Factors for Candidaemia in a Malaysian Tertiary Hospital
}

(Faktor Risiko untuk Kandidemia di Sebuah Hospital Tertier di Malaysia)

\author{
M.N. TZAR*, B. NORAZLAH \& A.S. SHAMSUL
}

\section{ABSTRACT}

Candidaemia carries high morbidity and mortality, but its conventional diagnosis is time consuming and insensitive. Clinical risk factors may identify suitable candidates for prophylactic or pre-emptive antifungal therapy and may be modified or controlled to prevent candidaemia. Therefore, this study aimed to identify the independent risk factors for candidaemia. The study was a retrospective, case-control study involving 54 patients with candidaemia and 54 patients without candidaemia as controls. The patient's data were collected from the medical records and the risk factors for candidaemia were analyzed in both groups. Candida species isolated from blood were C. tropicalis $(\mathrm{n}=19,35.2 \%)$, C. albicans $(\mathrm{n}=18,33.3 \%)$, C. parapsilosis $(\mathrm{n}=11,20.4 \%)$ and one isolate each $(1.9 \%)$ of C. famata, C. glabrata, C. krusei, C. melibiosica, C. pelliculosa and C. sake. Multivariate analysis showed that renal insufficiency, prior antibacterial therapy, prior antifungal therapy, steroid therapy and urinary catheterization were independent risk factors for candidaemia. Central venous catheter, prolonged hospital stay, intensive care unit stay, mechanical ventilation, surgery and parenteral nutrition occurred more commonly among the candidaemia group but were not independently significant. Controlling, limiting or modifying these risk factors may reduce the incidence of candidaemia.

Keywords: Bloodstream infection; Candida; candidaemia; risk factors

\section{ABSTRAK}

Kandidemia membawa kadar morbiditi dan kematian yang tinggi, namun kaedah diagnosis biasa memakan masa dan tidak sensitif. Faktor risiko klinikal boleh mengenal pasti calon sesuai untuk rawatan antikulat profilaktik atau pra-emptif dan boleh diubah atau dikawal bagi mencegah kandidemia. Oleh itu, kajian ini menyasarkan untuk mengenal pasti faktor risiko bebas untuk kandidemia. Kajian ini merupakan kajian kawalan kes retrospektif yang melibatkan 54 pesakit kandidemia dan 54 pesakit tanpa kandidemia sebagai kawalan. Data pesakit diperoleh daripada rekod perubatan dan faktor risiko dianalisis dalam kedua-dua kumpulan. Spesies candida yang dipencil daripada darah adalah C. tropicalis $(\mathrm{n}=19,35.2 \%)$, C. albicans $(\mathrm{n}=18,33.3 \%)$, C. parapsilosis $(\mathrm{n}=11,20.4 \%)$ dan satu pencilan setiap satu $(1.9 \%)$ dari C. famata, C. glabrata, C. krusei, C. melibiosica, C. pelliculosa dan C. sake. Analisis multivariat menunjukkan bahawa kerosakan ginjal, rawatan antibiotik terdahulu, rawatan antikulat terdahulu, rawatan steroid dan pengkateteran urin adalah merupakan faktor risiko bebas untuk mendapat kandidemia. Manakala kateter vena utama, inapan hospital berpanjangan, inapan unit kawalan intensif, pengalihudaraan mekanik, pembedahan dan nutrisi parenteral berlaku lebih kerap dalam kalangan pesakit kandidemia tetapi tidak signifikan. Mengawal, menghad atau mengubah faktor risiko ini boleh mengurangkan insiden kandidemia.

Kata kunci: Faktor risiko; jangkitan darah; candida; kandidemia

\section{INTRODUCTION}

Candidaemia remains the most frequent life-threatening fungal disease and is associated with excess mortality, a prolonged hospital stay and a resulting rise in costs (Morgan et al.2005). In order to effectively manage these patients, clinicians must recognize the risk factors associated with candidaemia and identify patients at increased risk, so that effective treatment can be offered and also for avoiding inappropriate administration of costly and toxic antifungal therapy (Patterson et al. 2006). The gold standard for the diagnosis of candidaemia is a positive blood culture; which should be obtained in all patients with suspected candidaemia. However, blood cultures are insensitive and serological methods, although more sensitive, are not widely used. Clinical risk factors may provide an early warning system to clinicians in identifying patients at risk so prophylaxis or pre-emptive antifungal therapy can be initiated. The risk factors may also be avoided, controlled or modified to prevent further occurrences of candidaemia in the future. Host-related risk factors refer to the underlying diseases of the patient, whereas treatment-related risk factors refer to instrumentation or medication given to the patient. Therefore this study aimed to determine the independent host-related and treatmentrelated risk factors for candidaemia.

\section{MATERIALS AND METHODS}

The study was a retrospective, unmatched 1:1 case-control study of all candidaemia cases in Universiti Kebangsaan 
Malaysia Medical Centre (UKMMC) from 1st June 2008 to 31 st December 2009. UKMMC is an 850-bedded, multidisciplinary tertiary level teaching hospital in Kuala Lumpur. A case of candidaemia was defined as a patient with at least one positive blood culture for Candida species. A control was defined as a patient who was admitted to the same ward with the case patient and had a positive blood culture but other than fungi. Cases or controls who were admitted within $48 \mathrm{~h}$ prior to the positive blood cultures and whose medical records were missing or incomplete were excluded from the study. Repeated episodes of candidaemia caused by the same species in the same patient within three months period were regarded as recurrent infection and were also excluded from the study. Data collected from the medical records included demography of cases and controls, types of Candida species isolated and the presence or absence of potential risk factors. The followings were only considered as potential risk factors if certain conditions were fulfilled in relation to the first episode of candidaemia: Diabetes mellitus, human immunodeficiency virus (HIV) infection, malignancy and renal insufficiency-if diagnosed at least 1 month before candidaemia; any major surgery requiring general anaesthesia, organ transplantation and parenteral nutrition - if done within 2 weeks before candidaemia; steroid therapy of a dose equivalent to at least $20 \mathrm{mg} /$ day prednisolone given for more than 7 days within 4 weeks before candidaemia; systemic antibacterial, systemic antifungal and chemotherapy - if given within 2 weeks before candidaemia; prolonged hospital stay was defined as hospital admission of more than 3 days before candidaemia; intensive care unit (ICU) stay was defined as ICU admission of more than $48 \mathrm{~h}$ before candidaemia; central venous catheter, urinary catheter and mechanical ventilation - if started at least $48 \mathrm{~h}$ before candidaemia; haemodialysis was defined as regular haemodialysis (usually three times a week); neutropaenia was defined as neutrophil counts of less than 500 cells $/ \mathrm{mm}^{3}$ and prematurity - a neonate who was born before 37 weeks of gestation and subsequently had candidaemia while in the hospital, within 28 days of life. Alcohol intake and cigarette smoking statuses of the study population were also noted. Statistical analysis of data was performed with Statistical Package for Social Sciences, using chi-square test for association between variables. A $p$-value of $<0.05$ was used to indicate statistically significant differences between the groups, and multivariate logistic regression was performed to detect independent risk factors. The study was approved by the Universiti Kebangsaan Malaysia Medical Research and Ethics Committee (UKM 1.5.3.5/244/SPP3).

\section{RESULTS}

A total of 54 candidaemia patients and 54 control subjects were enrolled during this study period. Men outnumbered women in the study population, with $65(60.2 \%)$ men and $43(39.8 \%)$ women (ratio 1.5:1). The race and age distributions between the candidaemia and control groups were not significantly different (Table 1 ). The majority of candidaemia cases came from the general ICU $(n=17$, $31.5 \%)$, followed by haematology wards $(n=9,16.7 \%)$, general medical wards $(n=7,13.0 \%)$ and surgical wards $(n=6,11.1 \%)$. Three cases each $(5.6 \%)$ from nephrology and general paediatrics wards; two cases each (3.7\%) from paediatric ICU, high dependency ward and bone marrow transplant unit and one case each $(1.9 \%)$ from the neonatal ICU, orthopaedics ward and burn unit. Candida species isolated in this study were C. tropicalis $(n=19$, $35.2 \%), C$. albicans $(n=18,33.3 \%), C$. parapsilosis $(n=11,20.4 \%)$ and one isolate each $(1.9 \%)$ of $C$. famata, C. glabrata, C. krusei, C. melibiosica, C. pelliculosa and $C$. sake. Bivariate analysis showed that there were eleven significant risk factors out of 21 with $p$ values less than 0.05 , which included renal insufficiency, surgery, antibacterial therapy, antifungal therapy, central venous catheter, hospital stay, ICU stay, mechanical ventilation,

TABLE 1. Demographic data of study population

\begin{tabular}{lccc}
\hline Characteristics & $\begin{array}{c}\text { Candidaemia } \\
n=54(\%)\end{array}$ & $\begin{array}{c}\text { Control } \\
n=54(\%)\end{array}$ & $p$-value \\
\hline Sex & & & 0.326 \\
$\quad$ Male & $30(55.6)$ & $35(64.8)$ & \\
Female & $24(44.4)$ & $19(35.2)$ & 0.143 \\
Race & & & \\
$\quad$ Malay & $29(53.7)$ & $38(70.4)$ & \\
Chinese & $14(25.9)$ & $12(22.2)$ & \\
Indian & $5(9.3)$ & $3(5.6)$ & \\
Others & $6(11.1)$ & $1(1.9)$ & \\
Ages in years $(n=54)$ & & & \\
$0-9$ (children) & $6(11.1)$ & $5(9.2)$ & \\
$10-19$ (adolescent) & $2(3.7)$ & $6(11.1)$ & \\
$20-50$ (young adults) & $17(31.5)$ & $14(26.0)$ & \\
$50-100$ (senior adults) & $29(53.7)$ & $29(53.7)$ & \\
Mean age & $45.13 \pm 6.08$ & $45.28 \pm 6.33$ & \\
\hline
\end{tabular}


parenteral nutrition, steroid therapy and urinary catheter (Table 2). However, in the final study model, the risk factors identified by multiple logistic regression analysis used to obtain estimates of risk after simultaneous control for other variables, only renal insufficiency, antibacterial therapy, antifungal therapy, steroid therapy and urinary catheter were significant predictors of candidaemia with p-values less than 0.05 (Table 3). From this study model summary, the variability explained by the predictors in the model is $74 \%$. We can conclude that this study provide good predictors for candidaemia cases (Table 4).

\section{DISCUSSION}

The gold standard for diagnosing candidaemia is still using blood culture, which is slow and insensitive; while serological and new methods such as matrix-assisted laser desorption ionization-time of flight mass spectrometry (MALDI-TOF MS), peptide nucleic acid fluorescent in situ hybridization (PNA-FISH) and T2 magnetic resonance methods offer a more rapid diagnosis but are not widely used (Vitale \& Nucci 2014). The recognition of a set of easily identifiable independent predictors for the occurrence of candidaemia in hospitalized patients will provide a rationale for implementing preventive measures and initiating antifungal prophylaxis in patients at risk even when the patient is not in an obvious immunocompromised state. When two or more of these risk factors are present, the probability of infection increases exponentially (Pfaller
\& Diekema 2007). This study showed that patients from all age groups were affected by candidaemia with the mean age of 45.13 years. The senior adults were more frequently affected $(53.7 \%)$, probably because they were more likely to have debilitating underlying medical conditions and other predisposing factors than younger patients. The seemingly high number of candidaemia cases among Malays turned out to be not significant. It merely reflected the racial distribution of the general Malaysian population. The distribution of Candida species isolated in this study showed a slightly different pattern when compared with a previous study done at the same centre in 2005 to 2006. In this study, $C$. tropicalis $(35.2 \%)$ formed the majority, followed by $C$. albicans $(33.3 \%)$ and $C$. parapsilosis (20.4\%); whereas the previous study reported the same 3 major species, but in a different order: C.albicans (40\%), C. tropicalis (32\%) and C. parapsilosis (10\%) (Tzar et al. 2009). In this study, non albicans Candida (NAC) species constituted $66.6 \%$ of all yeast isolates. This is similar to reports from the United Kingdom (Krcmery \& Barnes 2002) which showed $65 \%$ of candidaemia cases caused by NAC. In their study, 20 to $40 \%$ of isolates was $C$. parapsilosis followed by C.tropicalis (10-30\%), C. krusei and $C$. glabrata. In contrast, a study by Cheng et al. (2006) showed that $C$.albicans remains the most common isolate with $64.8 \%$ of the total isolates.

In this study, at the onset of candidaemia, all patients had at least two risk factors and the most common risk factor in this study was previous antibiotic

TABLE 2. Bivariate analysis of risk factors between candidaemia and control groups

\begin{tabular}{lccccc}
\hline Risk Factors & $\begin{array}{c}\text { Candidaemia } \\
(n=54)\end{array}$ & $\begin{array}{c}\text { Control } \\
(n=54)\end{array}$ & $p$-value & $\begin{array}{c}\text { Odds ratio } \\
(\text { OR })\end{array}$ & $\begin{array}{c}\text { RR } \\
\text { (OR with 95\% CI) }\end{array}$ \\
\hline Host-related factors & & & & & $0.55,3.52$ \\
Alcohol & 13 & 10 & 0.481 & 1.4 & $0.79,3.75$ \\
Diabetes mellitus & 25 & 18 & 0.169 & 1.7 & $0.06,16.40$ \\
HIV infection & 1 & 1 & 1.000 & 1.0 & $0.57,2.95$ \\
Malignancy & 18 & 15 & 0.531 & 1.3 & $0.45,39.23$ \\
Neutropenia & 17 & 10 & 0.120 & 2.0 & $1.49,7.72$ \\
Prematurity & 4 & 1 & 0.169 & 4.2 & $0.36,1.71$ \\
Renal insufficiency & 28 & 13 & $0.003^{*}$ & 3.34 & \\
Smoking & 20 & 23 & 0.555 & 0.8 & $4.68,283.46$ \\
Treatment-related factors & & & & & $3.99,243.15$ \\
Antibacterial therapy & 53 & 32 & $0.000^{*}$ & 36.4 & $1.62,17.02$ \\
Antifungal therapy & 20 & 1 & $0.000^{*}$ & 31.1 & $0.56,3.12$ \\
Central venous catheter & 50 & 38 & $0.003^{*}$ & 5.2 & $0.95,6.96$ \\
Chemotherapy & 16 & 13 & 0.515 & 1.3 & $2.60,54.87$ \\
Hemodialysis & 15 & 7 & 0.056 & 2.6 & $1.23,5.89$ \\
Hospital stay & 52 & 37 & $0.000^{*}$ & 11.9 & $1.32,6.32$ \\
ICU stay & 31 & 18 & $0.012^{*}$ & 2.7 & $0.39,7.62$ \\
Mechanical ventilation & 33 & 19 & $0.007^{*}$ & 2.9 & $1.62,17.02$ \\
Organ transplant & 5 & 3 & 0.452 & 1.7 & $1.14,6.32$ \\
Steroid therapy & 16 & 4 & $0.003^{*}$ & 5.2 & $2.52,18.80$ \\
Surgery & 22 & 11 & $0.022^{*}$ & 2.7 & $2.77,18.82$ \\
Total parenteral nutrition & 25 & 6 & $0.000^{*}$ & 6.9 & 7.2 \\
Urinary catheter & 47 & 26 & $0.000^{*}$ & & \\
\hline
\end{tabular}

*denotes significant risk factors, $p<0.05$ 
exposure followed by a prolonged hospital stay. Bivariate analysis identified several significant risk factors for candidaemia: Renal insufficiency, previous antibacterial therapy, previous antifungal therapy, central venous catheterization, prolonged hospital stay, prolonged ICU stay, use of mechanical ventilation, steroid therapy, surgery, total parenteral nutrition and urinary catheterization. However, after performing multivariate logistic regression analysis to remove the confounders, only five risk factors remained significant: one host-related factor i.e. renal insufficiency and four treatment-related factors i.e. previous antibacterial therapy, previous antifungal therapy, steroid therapy and urinary catheterization. Humoral and cell-mediated immunity are depressed in patients with acute renal failure thus candidaemia may become prevalent in patients with acute renal failure if they survive longer due to advances in intensive care and dialysis therapy (Sung et al. 2001). Confirming earlier reports (Bassetti et al. 2007; Blumberg et al. 2001; Bross et al. 1989; Sung et al. 2001; Wey et al. 1989), our study showed that renal insufficiency was independently related to candidaemia in the logistic regression model.

Our study did not find other significant host-related factors, which is in contrast to other studies that reported diabetes mellitus (Michalopoulos et al. 2003; Wu et al. 2014), HIV infection (Chowta et al. 2007; Petrosillo et al. 2002), malignancy (Zaoutis et al. 2010) and prematurity (Saiman et al. 2000; Wu et al. 2013), as significant risk factors. This could possibly due to several factors - our small sample size, particularly for HIV infection and prematurity; different study population by Zaoutis et al. (2010) who included only paediatric patients and diabetes mellitus being too prevalent in our population that it is present too often in both groups. As Candida is part of oropharyngeal flora, our study included cigarette smoking and alcohol intake as possible lifestyle factors for candidaemia. Studies have shown that exposure to cigarette smoke enhances the virulence of Candida albicans, which may lead to prolonged oral colonization (Baboni et al. 2009; Semlali et al. 2014). However, our study did not find any significant association between smoking and candidaemia. A recent study has shown that patients with severe alcoholic hepatitis are at an increased risk of developing invasive mycosis including candidaemia (Lahmer et al. 2014). Another study showed a higher incidence of Candida albicans and bacteria in the cultures of pharyngeal smears of alcoholics than the non-alcoholics (Fernández-Solá et al. 1995). However, our study did not show any significant association between alcohol intake and candidaemia.

Out of five significant independent risk factors for candidaemia identified, four were treatment-related factors, viz. antibacterial therapy, antifungal therapy, steroid therapy and urinary catheterization (Table 3). Antibacterial therapy, especially multiple agents, broad spectrum, high antianaerobic activity and high gastrointestinal concentration may preferentially suppress the normal bowel flora and lead to gastrointestinal colonization with Candida species (Akbar \& Tahawi 2001; Bross et al. 1989; Cheng et al. 2006; Wey et al. 1989; Zaoutis et al. 2010). Meanwhile, patients who had prior antifungal therapy were found to be four times more likely to develop candidaemia (Table 2). However, it did not predict whether the causative organism was a non-albicans Candida ( $p=0.771$; data not shown). A study by Feja et al. (2005) reported that prior antifungal therapy was a significant risk factor in the initial analysis but became insignificant after the multivariate analysis. Conversely, other studies found that prior antifungal therapy was a significant independent risk factor for developing candidaemia caused by non-albicans Candida (Almirante et al. 2006; Playford et al. 2008). Even though modern antifungal therapy has facilitated prophylaxis and treatment for invasive fungal infections in high risk patients, breakthrough candidaemia has been reported to be increasing (Pasqualotto et al. 2006). Therefore, antimicrobial stewardship program is strongly suggested to be put in place at healthcare institutions (Valerio et al. 2014). Corticosteroid therapy can depress humoral and cellular immunity, which are vital defence mechanisms for preventing deep tissue invasion by Candida (Sung et al. 2001). Our study showed that steroid therapy was an independent risk factor for candidaemia,

TABLE 3. Multivariate logistic regression analysis of risk factors for candidaemia

\begin{tabular}{lccc}
\hline Risk Factors & Significant $(p$-value $)$ & Lower 95\% CI & Upper 95\% CI \\
\hline Antibacterial therapy & $0.030^{*}$ & 1.380 & 498.000 \\
Antifungal therapy & $0.011^{*}$ & 2.345 & 656.793 \\
Central venous catheter & 0.251 & 0.424 & 26.545 \\
Hospital stay & 0.191 & 0.448 & 55.525 \\
ICU stay & 0.604 & 0.195 & 16.571 \\
Mechanical ventilation & 0.769 & 0.074 & 6.862 \\
Renal insufficiency & $0.016^{*}$ & 1.403 & 28.595 \\
Steroid therapy & $0.004^{*}$ & 3.691 & 819.386 \\
Surgery & 0.693 & 0.153 & 3.491 \\
Total parenteral nutrition & 0.130 & 0.684 & 19.049 \\
Urinary catheter & $0.006^{*}$ & 2.326 & 136.915 \\
\hline
\end{tabular}

*denotes significant independent risk factors, $p<0.05$ 
TABLE 4. Study model summary

\begin{tabular}{cccc}
\hline Step & -2 Log Likelihood & $\begin{array}{c}\text { Cox \& Snell R } \\
\text { square }\end{array}$ & $\begin{array}{c}\text { Nagelkerke R } \\
\text { square }\end{array}$ \\
\hline $\mathrm{I}$ & $62.28(\mathrm{a})$ & .555 & .740 \\
\hline
\end{tabular}

confirming a prior report by Han et al. (2010). In contrast, other studies found that steroid therapy was not associated with risk of developing candidaemia (Blumberg et al.2001; Cheng et al. 2006). In fact, maternal steroid was found to be an independent protective factor against candidaemia in neonates (Linder et al. 2004). However, the exact mechanism is unclear. Urinary catheters and other invasive measures create numerous potential portals of entry for bacterial and mycotic pathogens. Our study showed that urinary catheter usage predisposed to candidaemia with a relative risk of 2.77 (Table 2), which is in line with findings by other studies (Bross et al. 1989; Saiman et al. 2000). Other studies reported that central venous catheterization (Bassetti et al. 2007; Petrosillo et al. 2002; Wu et al. 2013), prolonged hospital stay (Bassetti et al. 2007; Petrosillo et al. 2002), ICU stay (Amrutkar et al. 2006), mechanical ventilation (Saiman et al. 2000), surgery (Blumberg et al. 2001; Playford et al. 2008; Wu et al. 2013) and total parenteral nutrition (Amrutkar et al. 2006; Bassetti et al. 2007; Blumberg et al. 2001) were significant risk factors for candidaemia. However, our study found that these risk factors were only significant in bivariate analysis but were insignificant after multivariate logistic regression analysis; indicating that although these factors were more commonly found among patients with candidaemia that those without, statistically they were not considered significant independent risk factors for candidaemia in our study.

The authors acknowledge several limitations of the study. Firstly, this study was a retrospective study resulting in the exclusion of a few cases due to missing data and several biases may exist such as reporting bias and sampling bias. Hence, a prospective study is more preferable. Secondly, this study was a single-centred study; therefore the study population may not be representative of the actual population in other hospitals in the country. Small sample size in some categories of risk factors may influence accurate assessment of the risk factors for candidaemia. Thirdly, prognostic indicators such as inadequate initial therapy, source of candidaemia and susceptibility of the isolate to the antifungal drugs also were not evaluated in this study.

\section{CONCLUSION}

This study has identified five independent risk factors for candidaemia, which are prior antibacterial therapy, prior antifungal therapy, steroid therapy, urinary catheterization and renal insufficiency. Controlling, limiting or modifying these factors may reduce the incidence of candidaemia.

\section{ACKNOWLEDGEMENTS}

This study was funded by UKMMC Fundamental Research Grant (project code was FF-059-2009).

\section{REFERENCES}

Akbar, D.H. \& Tahawi,A.T. 2001. Candidaemia at a University Hospital: Epidemiology, risk factors and predictors of mortality. Ann. Saudi Med. 21: 3-4.

Almirante, B., Rodriguez, D., Cuenca-Estrella, M., Almela, M., Sanchez, F., Ayata, J., Alonso-Tarres, C., Rodriguez-Tudela, J.L., Pahissa, A. \& the Barcelona Candidemia Project Study Group. 2006. Epidemiology, risk factors, and prognosis of Candida parapsilosis bloodstream infections: Case-control population-based surveillance study of patients in Barcelona, Spain, from 2002 to 2003. J. Clin.Microbiol. 44: 1681-1685.

Amrutkar, P.P., Rege, M.D., Chen, H., LaRocco, M.T., Gentry, L.O. \& Garey, K.W. 2006. Comparison of risk factors for candidaemia versus bacteraemia in hospitalized patients. Infection 34: 322-327.

Baboni, F.B., Barp, D., de Azevedo Izidoro,A.C.S., Samaranayake, L.P. \& Rosa, E.A.R. 2009. Enhancement of Candida albicans virulence after exposition to cigarette mainstream smoke. Mycopathologia 168(5): 227-235.

Bassetti, M., Trecarichi, E.M., Righi, E., Sanguinetti, M., Bisio, F., Posteraro, B., Soro, O., Cauda, R., Viscoli, C. \& Tumbarello, M. 2007. Incidence, risk factors, and predictors of outcome of candidaemia. Survey in 2 Italian university hospitals. Diagn. Microbiol. Infect. Dis. 58: 325-331.

Blumberg, H.M., Jarvis, W.R., Soucie, J.M., Edwards, J.E., Patterson, J.E., Pfaller, M.A., Rangel-Frausto, M.S., Rinaldi, M.G., Saiman, L., Wiblin, R.T., Wenzel, R.P. \& the NEMIS Study Group. 2001. Risk factors for candidal bloodstream infections in surgical intensive care unit patients: The NEMIS prospective multicentre study: The National Epidemiology of Mycosis Survey. Clin. Infect. Dis. 33(2): 177-186.

Bross, J., Talbot, G.H., Maislin, G., Hurwitz, S. \& Strom, B.H. 1989. Risk factors for nosocomial candidaemia: A casecontrol study in adults without leukaemia. Am. J. Med. 87(6): 614-620.

Cheng, Y.R., Lin, L.C., Young, T.G., Liu, C.E., Chen, C.H. \& Tsay, R.W. 2006. Risk factors for candidaemia-related mortality at a medical centre in central Taiwan. J. Microbiol. Immunol. Infect. 39: 155-161.

Chowta, M.N., Adhikari, P., Rajeev, A. \& Shenoy, A.K. 2007. Study of risk factors and prevalence of invasive candidiasis in a tertiary care hospital. Indian J. Crit. Care Med.11(2): 67-73.

Feja, K.N., Wu, F., Roberts, K., Loughrey, M., Nesin, M., Larson, E., Della-Latta, P., Haas, J., Cimiotti, J. \& Saiman, L. 2005. Risk factors for candidemia in critically ill infants: A matched case-control study. J. Pediatr. 147: 156-161.

Fernández-Solá, J., Junqué,A., Estruch, R., Monforte, R., Torres, A. \& Urbano-Márquez, A. 1995. High alcohol intake as a risk and prognostic factor for community-acquired pneumonia. Arch. Intern. Med. 155(15): 1649-1654. 
Han, S.S., Yim, J.J., Yoo, C.G., Kim, Y.W., Han, S.K., Shim, Y.S. \& Lee, S.M. 2010. Clinical characteristics and risk factors for nosocomial candidaemia in medical intensive care units: Experience in a single hospital in Korea for 6.6 years. $J$. Korean Med. Sci. 25: 671-676.

Krcmery, V. \& Barnes, A.J. 2002. Non-albicans Candida spp. causing fungaemia: Pathogenicity and antifungal resistance. J. Hosp. Infect. 50: 243-260.

Lahmer, T., Messer, M., Schwerdtfeger, C., Rasch, S., Lee, M., Saugel, B., Schmid, R.M. \& Huber, W. 2014. Invasive mycosis in medical intensive care unit patients with severe alcoholic hepatitis. Mycopathologia 177(3-4): 193-197.

Linder, N., Levit, O., Klinger, G., Kogan, I., Levy, I., Shalit, I., Ashkenaze, S. \& Sirota, L. 2004. Risk factors associated with candidaemia in the neonatal intensive care unit: A casecontrol study. J. Hosp. Infect. 57: 321-324.

Michalopoulos, A.S., Geroulanos, S. \& Mentzelopoulos, S.D. 2003. Determinants of candidemia and candidemia-related death in cardiothoracic ICU patients. Chest. 124(6): 22442255.

Morgan, J., Meltzer, M.I., Plikaytis, B.D., Sofair, A.N., HuieWhite, S., Wilcox, S., Harrison, L.H., Seaberg, E.C., Hajjeh, R.A. \& Teutsch, S.M. 2005. Excess mortality, hospital stay, and cost due to candidemia: A case-control study using data from population-based candidemia surveillance. Infect. Control Hosp. Epidemiol. 26(6): 540-547.

Pasqualotto, A.C., Nedel, W.L., Machado, T.S. \& Severo, L.C. 2006. Risk factor and outcome for nosocomial breakthrough candidaemia. J. Infect. 52: 216-222.

Patterson,T.F. 2006. Fungal infection in the immunocompromised patient: Risk assessment and the role of antifungal agents. http://www.medscape.com/viewprogram/5791.Accessed on 15 August 2014.

Petrosillo, N., Viale, P., Nicastri, E., Arici, C., Bombana, E., Casella, A., Cristini, F., De Gennaro, M., Dodi, F., Gabbuti, A., Gattuso, G., Irato, L., Maggi, P., Pallavicini, F., Pan, A., Pantaleoni, M., Ippolito, G. for Gruppo HIV e Infezioni Ospedalierea. 2002. Nosocomial blood stream infections among human immunodeficiency virus infected patients: Incidence and risk factors. Clin. Infect. Dis. 34: 677-685.

Pfaller, M.A. \& Diekema, D.J. 2007. Epidemiology of invasive candidiasis: A persistent public health problem. Clin. Microbiol.Rev. 20: 133-163.

Playford, E.G., Marriott, D., Nguyen, Q., Chen, S., Ellis, D., Slavin, M. \& Sorrell, T.C. 2008. Candidaemia in nonneutropenic critically ill patients: Risk factors for nonalbicans Candida spp. Crit. Care Med.36(7): 177-183.

Saiman, L., Ludington, E., Pfaller, M., Rangel-Frausto, S., Wiblin, R.T., Dawson, J., Blumberg, H.M., Patterson, J.E., Rinaldi, M., Edwards, J.E., Wenzel, R.P. \& Jarvis, W. 2000. Risk factors for candidemia in neonatal intensive care unit patients. The National Epidemiology of Mycosis Survey study group. Pediatr. Infect. Dis. J. 19(4): 319-324.
Semlali,A., Killer, K.,Alanazi,H.,Chmielewski,W. \& Rouabhia, M. 2014. Cigarette smoke condensate increases $C$. albicans adhesion, growth, biofilm formation, and EAP1,HWPI and SAP2 gene expression. BMC Microbiol. 14: 61.

Sung, J.M., Ko, W.C. \& Huang, J.J. 2001. Candidaemia in patients with dialysis dependent acute renal failure: Aetiology, predisposing and prognostic factors. Nephrol. Dial. Transplant 16: 2348-2356.

Toya, S.P., Schraufnagel, D.E. \& Tzelepis, G.E. 2007. Candiduria in intensive care units: Association with heavy colonization and candidaemia. J. Hosp. Infect. 66: 201-206.

Tzar, M.N. \& Shamim, A.S. 2009. Candidaemia and antifungal susceptibility testing in a teaching hospital.Med.J.Malaysia 64: 61-64

Valerio, M., Rodriguez-Gonzalez, C.G., Muñoz, P., Caliz, B., Sanjurjo, M., Bouza, E. on behalf of the COMIC Study Group (Collaborative Group on Mycoses). 2014. Evaluation of antifungal use in a tertiary care institution: Antifungal stewardship urgently needed. J. Antimicrob. Chemother. 69: 1993-1999.

Vitale, R.G. \& Nucci, M. 2014. Diagnosis of candidemia. Curr. Fungal Infect. Rep. 8: 90-94.

Wey, S.B., Mori, M., Pfaller, M.A., Woolson, R.F. \& Wenzel, R.P. 1989. Risk factors for hospital-acquired candidemia: A matched case-control study. Arch. Intern. Med. 149(10): 2349-2353.

Wu, Z., Liu, Y., Feng, X., Liu, Y., Wang, S., Zhu, X., Chen, Q. \& Pan, S. 2014. Candidemia: Incidence rates, type of species, and risk factors at a tertiary care academic hospital in China. Int. J. Infect. Dis. 22: 4-8.

Zaoutis, T.E.,Prasad, P.A., Localio, A.R.,Coffin, S.E., Bell,L.M., Walsh, T.J. \& Gross, R. 2010. Risk factors and predictors for candidemia in pediatric intensive care unit patients: Implications for prevention. Clin. Infect. Dis. 51: e38-e45.

M.N. Tzar* \& B. Norazlah

Department of Medical Microbiology and Immunology

Universiti Kebangsaan Malaysia Medical Centre

Jalan Yaacob Latif, 56000 Cheras, Kuala Lumpur Malaysia

\section{A.S. Shamsul}

Department of Community Health

Universiti Kebangsaan Malaysia Medical Centre

Jalan Yaacob Latif, 56000 Cheras, Kuala Lumpur Malaysia

*Corresponding author; email: tzar@ppukm.ukm.edu.my

Received: 21 November 2014

Accepted: 22 January 2015 